\title{
Mission as breaking down walls, opening gates and empowering traders: From contextualisation to deep contextualisation
}

\begin{tabular}{|c|c|}
\hline \multicolumn{2}{|c|}{$\begin{array}{l}\text { Author: } \\
\text { Cornelius J.P. Niemandt }{ }^{1} \text { (D) }\end{array}$} \\
\hline \multicolumn{2}{|c|}{$\begin{array}{l}\text { Affiliation: } \\
\text { 1Department Science of } \\
\text { Religion and Missiology, } \\
\text { University of Pretoria, } \\
\text { South Africa }\end{array}$} \\
\hline \multicolumn{2}{|c|}{$\begin{array}{l}\text { Research Project Registration: } \\
\text { Project Leader: N. Niemandt } \\
\text { Project Number: } 04317734\end{array}$} \\
\hline \multicolumn{2}{|c|}{$\begin{array}{l}\text { Description: } \\
\text { This research is part of the } \\
\text { research project, 'Ecodom } \\
\text { directed by Prof. Dr Nelus } \\
\text { Niemandt, Department of } \\
\text { Science of Religion and } \\
\text { Missiology, Faculty of } \\
\text { Theology, University of } \\
\text { Pretoria. }\end{array}$} \\
\hline \multicolumn{2}{|c|}{$\begin{array}{l}\text { Corresponding author: } \\
\text { Cornelius Niemandt, } \\
\text { nelus.niemandt@up.ac.za }\end{array}$} \\
\hline \multicolumn{2}{|c|}{$\begin{array}{l}\text { Dates: } \\
\text { Received: } 01 \text { May } 2017 \\
\text { Accepted: } 04 \text { June } 2017 \\
\text { Published: } 31 \text { Aug. } 2017\end{array}$} \\
\hline \multicolumn{2}{|c|}{$\begin{array}{l}\text { How to cite this article: } \\
\text { Niemandt, C.J.P., 2017, } \\
\text { 'Mission as breaking down } \\
\text { walls, opening gates and } \\
\text { empowering traders: From } \\
\text { contextualisation to deep } \\
\text { contextualisation', HTS } \\
\text { Teologiese Studies/ } \\
\text { Theological Studies 73(1), } \\
\text { 4621. https://doi.org/ } \\
\text { 10.4102/hts.v73i1.4621 }\end{array}$} \\
\hline \multicolumn{2}{|c|}{$\begin{array}{l}\text { Copyright: } \\
\text { (C) 2017. The Authors. } \\
\text { Licensee: AOSIS. This work } \\
\text { is licensed under the } \\
\text { Creative Commons } \\
\text { Attribution License. }\end{array}$} \\
\hline \multicolumn{2}{|l|}{ Read online: } \\
\hline 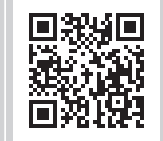 & $\begin{array}{l}\text { Scan this QR } \\
\text { code with your } \\
\text { smart phone or } \\
\text { mobile device } \\
\text { to read online. }\end{array}$ \\
\hline
\end{tabular}

The research addressed the issue of symbolic walls that divide, segregate, preserve and institutionalise. The way in which institutions and especially the Faculty of Theology at the University of Pretoria facilitated symbolic 'walls' was discussed in the overview of the Department of Science of Religion and Missiology in the first century of the Faculty of Theology. The concepts of 'gatekeepers' and 'traders' were then applied because walls, paradoxically, need gates to facilitate control, movement and, eventually, life. Gatekeepers were described as the guardians of the status quo, and traders as agents who, in one way or another, facilitate movement, trade, flow and life in the midst of the shadows of walls. Missionaries are, by the very nature of the missionary enterprise, more traders than gatekeepers. Here, the work of Bosch - specifically his ground-breaking work on mission as contextualisation - provides an explanation of the art of mission as breaking down walls, opening gates and empowering traders. That is precisely why Missiology is particularly well suited to assist the church and theology in the art of breaking down walls. The theological imperative of contextualisation means that the life of the church, theology, and thus theological training, cannot do without Missiology. The concept of 'deep contextualisation' was discussed as a particularly relevant approach to include a postanthropomorphic discourse in Missiology. It can assist with the reorientation of the history of mission on the whole of history and, thus, also deep history. The concept also provides a way to address the discourses on colonialisation and includes a reorientation on the future and embracing hope.

\section{Breaking down walls through art}

Wikipedia describes Banksy as an anonymous England-based graffiti artist, political activist and film director of unverified identity. Banksy is more than a single artist - it is a movement of social activists: 'Their satirical street art and subversive epigrams combine dark humour with graffiti executed in a distinctive stencilling technique. Banksy's works of political and social commentary have been featured on streets, walls, and bridges of cities throughout the world' (Wikipedia 2017).

Banksy's art is especially visible on walls and places that divide, leaving huge statements on the injustices of divisions and political power plays. It should come as no surprise, then, that many of these graffiti murals are found on the wall dividing Palestinians and Israelis.

This mural (Figure 1) serves as a powerful icon of many other famous walls: The original wall built by Nehemiah to safeguard ancient Jerusalem; the great wall in China; the monstrous wall that divided East and West during the Cold War; the mostly symbolic, but just as powerful, wall of apartheid signs that divided South Africa with just four words 'Slegs Blankes, Whites only'; the wall running through huge areas of Palestine, separating Arabs and Israelis; and, of course, Donald Trump's dream of a wall that will keep all migrants and foreigners out of the nation of migrants and foreigners, the Un-united States of America.

Walls divide. Walls segregate, preserve and institutionalise. Walls safeguard borders, identities, wealth. Walls are, by nature, static, immovable, stark and dark. They beg artists to make statements and to transform the dullness and cold isolation associated with walls. Sometimes, artists protest more than just the physical barriers. They shout out at the walls found in everyday life, in the workplace and classrooms and, perhaps, universities. Who, from my generation, will ever forget Pink Floyd? 


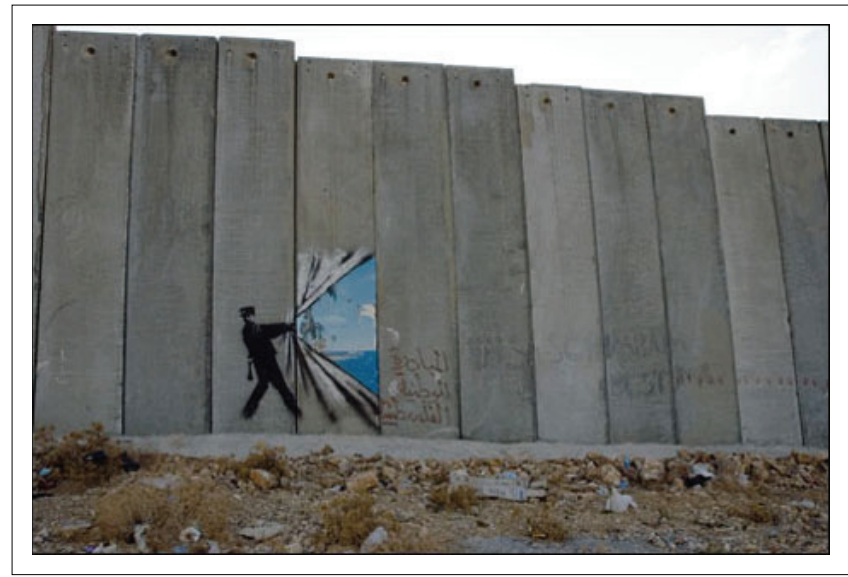

Source: Banksy, 2017, Graffiti by Banksy, viewed 11 June 2017, from https://za.pinterest com/pin/5683684154446880021/

FIGURE 1: Banksy mural on the West Bank Barrier, Qalqilya.

We don't need no education

We don't need no thought control

No dark sarcasm in the classroom

Teachers leave them kids alone

Hey! Teachers! Leave them kids alone!

All in all it's just another brick in the wall.

All in all you're just another brick in the wall. ${ }^{1}$

\section{Gatekeepers and traders}

Walls, paradoxically, need gates to facilitate control, movement and, eventually, life. All the great walls have had points of entry, gates and checkpoints: Just think about the iconic status of Checkpoint Charlie in Berlin during the height of the Cold War. Checkpoints and gates have gatekeepers. Gatekeepers represent a concentration of power, systems that regulate the flow and the mechanics of inclusion and exclusion. Gatekeepers are the guardians of the status quo. They must ensure stability, fidelity and control. Gatekeepers keep things separate, apartheid intact and foreigners out.

But, you also find 'traders' in close proximity to gates and walls. They are the agents who, in one way or another, facilitate movement, trade, flow and life in the midst of the shadows of walls. All complex systems end up with walls and gates, as well as gatekeepers and traders, in an intricate movement to manage the flow between 'this side' and 'that side'. The life and actions of a complex system, such as denominations and universities, are influenced by the relationship between 'traders' and 'gatekeepers' in the system. Traders are at the forefront of change. They are the 'innovators' and 'early adopters' in the system (Keifert 2006:55). Traders ring in changes and introduce new grammar, ideas and innovation. They find ways through the wall, secret messages through the cracks so that vital information can flow. They find gateways and alleys that can circumvent or break through barriers so that interaction and exchange can happen. A description by Haight (2014) comes to mind when he describes the 'Anthropology of Constructive Action':

1.Pink Floyd, Another Brick in the Wall - Part 2.
God has entrusted creation to human beings not merely as caretakers of a past condition but as co-creators with God of the future. This formula corresponds with the recognition that being is not static but in process, and that human beings were created by God not simply to enjoy creation but, as part of the universe, to work with the processes of evolution and to assume responsibility for its historical movement. (p. 55)

Big systems, denominations, even countries, need traders. Friedman (2016:306) makes a compelling case for the same posture when he says that the most resilient countries and systems are those that are able to absorb many alien influences and incorporate them into the system while maintaining overall stability. The age of acceleration, where mankind's ability to keep up with change becomes severely challenged, demands: 'interdependencies that embrace the immigrant, the stranger, and the loner, and inspire more people in more places to want to make this rather than break things' (Friedman 2016:350).

Gatekeepers see themselves as custodians of the past and traditions in the system. They guard the identity of the system. They manage the flow and keep things apart so that they do not fall apart. If we think back and remember the 100 years of the Faculty of Theology at the University of Pretoria, we are able to recall the gatekeepers. In this particular intersection between church and university, gatekeepers appointed members of faculty that, they hoped, would not challenge the dominant apartheid systems. They tried their utmost to close off and exclude the traders who challenged and exposed, and opened up. More recently, in the Dutch Reformed Church, gatekeepers manipulated church orders and procedural rules so that the church could (can) keep people of homosexual orientation out of church offices such as ordained ministers, and outside the power systems (Kerkbode 2015). Smit (2016) described the situation in the Dutch Reformed Church as one of order and control, where power was used to keep control of policy-making meetings and to exclude those who represent a threat to the status quo.

That is precisely why church boards of control (curatoria) and structures tasked with the interpretation and application of the church order (church polity committees) of a denomination will attract more gatekeepers than traders, and such teams are naturally inclined to see their role as custodians of the tradition and identity, rather than agents of change. This opens the way for using church polity to control the flow of transformation and change in the system. The fact that actuarii (officials tasked with the interpretation of church polity and the application of church rules) and polity committees can give substantial guidance on the 'interpretation and application' of the church order, combined with the fact that there is no formal review of guidance by actuarii, grants exceptional structural powers to actuarii, stymies creative adaptive changes and, eventually, the missional character of the church. Church polity is institutionalised in written codes and policy documents that order church life. These written systems represent a particular expression of power. Fairclough (2013:41) refers to the power of the written language. It is a one-sided discourse, with a 
sharp divide between producers and interpreters. Church polity documents represent the epitome of power in denominations as written tracts that determine church life.

Meylahn (2012:32) warns against a response to this fastchanging world in which the church tries to create a safe ghetto space - sometimes by literally barricading the church with high walls and security systems. Such a church will become 'a little enclave where things stay the same and offer individuals exactly what they believe they need - a safe space/a true home' (Meylahn 2012:33).

The same applies to the systemic barricades found in church order and, more particularly, the way in which these organising documents are applied in denominations.

\section{Missionaries as traders}

Missionaries are, by the very nature of the missionary enterprise, more traders than gatekeepers. They are more focussed on finding creative solutions and prone to be caught up in a mission to expend their talents for a selftranscending cause (Haight 2014:77). No wonder many a missionary tale will relate how the missionary scaled walls, travelled by secret routes, and smuggled Bibles and missionary messages to those on the 'other side'. Missionaries reach out to the 'other', welcome strangers, find their way through walls and gates, and eat what is put before them. And yes, just sometimes, they break down the walls; witness the walls of apartheid and the patient deconstruction (what a civilised word for 'breaking down walls') of apartheid by missionaries, churches and architects of transformation; witness David Bosch, author of that great treatise of deconstruction, Transforming mission (1992), and his role in SACLA ${ }^{2}$ in public witnessing and in the breaking down of the walls of apartheid - a real trader and missionary if there ever was one. Kritzinger and Saayman (2011:73) explain: 'Bosch rejected the apartheid policy (the Afrikaners' theological-ideological political project of social engineering) because of deeply-held theological convictions. By doing this, he placed himself "outside the Afrikaner camp" (Heb 13:13), without actually leaving it'. Bosch became an icon in his struggle for justice and his ability to stand in the gap (to create gates in walled communities!) and help opposing people to accept and respect each other.

Although a Faculty of Theology is embedded in many power systems that determine the nature of a faculty as well as the research and formation of the student body, a faculty of theology is most fundamentally characterised by the embodied presence of the people that constitutes a faculty - the students and researchers and especially the members of faculty. The real power and influence of any faculty are found in the human factor and the way in which academics shape the future through their personalities, intellect, commitment, and presence. The interaction at the

$2.5 A C I A-T h e$ South African Church Leaders Assembly - convened from 08 to 17 july 1979 in Pretoria to bring together a wide range of South African and international church leaders to protest against apartheid. Prof. David Bosch played an important role in the organisation and chaired SACLA. gate between gatekeepers and traders shapes the flow of knowledge and formation. When one enters the gateway to the future from a deconstructed past, the memories of many alumnii and emeriti of the Faculty of Theology at the University of Pretoria, many traders and gatekeepers, fill the space and collective history: Students such as Jaco Beyers, David Bosch, Murray Hofmeyer, Hannes Knoetze, Klippies Kritzinger, Arno Meiring and Pieter Verster. Emeritii such as Carel Boshoff, Dionne Crafford, HDA du Toit, Thias Kgatla, Dons Kritzinger, Piet Meiring, Piet van der Merwe and Attie van Niekerk.

This begs the 'what if ...' question. What if Thias Kgatla could have joined the team as a member of faculty a decade or two earlier? What if David Bosch could have extended his phenomenal presence in a more direct way as not only an alumnus but also as lecturer - especially if one considers the fact that he was twice invited for interviews when vacancies for a professor in Missiology were to be filled in the Faculty of Theology (then called Section B - the Dutch Reformed section of the Faculty of Theology) and that he was rejected in both instances? ${ }^{3}$ The gatekeepers were all too successful in keeping him out, but he fortunately found other ways to break through the wall. He could not do otherwise than battle the walls, because he understood mission as a road (with a necessary spirituality of the road) and not as a wall. He fundamentally understood the dynamic nature of mission (and as academic discipline) as transforming mission, and he gave words and wings to the concept of mission as contextualisation. He did not only chisel away at the walls of apartheid, but tackled the even stronger and overwhelming presence of the 'Enlightenment', one of the 'Grand Ideologies' of our time (Bosch 1995:19). One can even imagine Bosch nodding in agreement at the conference theme during the centenary celebrations of the Faculty of Theology in 2017: Gateway to the Future from a Deconstructed Past. He argued that the Christian Church is always in the process of becoming: 'the church of the present is both the product of the past and the seed of the future' (Bosch 1991:422).

If there ever was an explanation of the art of mission as breaking down walls, opening gates and empowering traders, then it can be found in his description of mission as contextualisation.

\section{Contextualisation}

Contextualisation recognises the contextual nature of faith, and the fact that interpreting the Biblical text has social, economic and political implications. Bosch (1991) argued:

\footnotetext{
3.In an interview with Prof Piet Meiring on 20 February 2017, he related the story where David Bosch was invited to an interview for a vacancy in the position as professor in Missiology in 1988: When the curatorium asked the candidates to professor in Missiology in 1988: When the curatorium asked the candidates to
mention the current state of affairs in Missiology, most of us referred to the work of mention the current state of affairs in Missiology, most of us referred to the work of
David Bosch as an international trendsetter in Missiology. I was extremely surprised when I was appointed in the position, and not David. (Meiring 2017)

Incredibly enough, Bosch was also not appointed when an opportunity to appoint a Senior Lecturer at the Faculty of Theology of the University of Stellenbosch opened up. The very person who received the appointment, Prof. Nico Smith, said opened up. The very person who received the appointment, Prof. Nico Smith, said
that Bosch was rejected because he was an open critic of the apartheid policy (Kritzinger \& Saayman 2011:74)
} 
... every text is an interpreted text and that, in a sense, the reader 'creates' the text when she or he reads it. The text is not only 'out there', waiting to be interpreted; the text 'becomes' as we engage with it. And yet, even this new hermeneutic approach is not going far enough. Interpreting a text is not only a literary exercise; it is also a social, economic, and political exercise. (p. 423)

The following (all brief) points might explain more of Bosch's understanding of contextualisation:

- Mission as contextualisation is an affirmation that God has turned toward the world. The world is a constitutive element in our understanding of mission (Bosch 1991:426).

- Mission as contextualization involves the construction of a variety of 'local theologies'. Theology is experimental and there is an ongoing dialogue between text and context (Bosch 1991:427).

- This is why discernment is such an important issue. Discernment is the first and most decisive step on the missional journey - the first act of mission (Kim 2009:34). Discernment is the art of 'reading the signs of the times' (Bosch 1991:429). This also means that the message of the gospel is not something we bring to contexts, but something we derive from contexts (Bosch 1991:430).

- The best models of contextual theology succeed in holding together in creative tension theoria, praxis, and poiesis. Poiesis is the 'imaginative creation or representation of evocative images', because people need truth (theory), justice (praxis), and beauty (Bosch 1991:431).

- Bosch also warns of the danger of relativism, where each context forges its own theology, tailor made for that specific context, but also the danger of absolutism of contextualism (Bosch 1991:428).

The growth of the church in every culture of the world makes the issue of contextualisation - the relation of the gospel and church to its cultural context - an important one (Goheen 2014:loc.438-439). Bevans and Schroeder (2004:386) emphasise that contextualisation is a theological and missional imperative. That is precisely why Missiology is particularly well suited to assist the church and theology in the art of crossing borders. The theological imperative of contextualisation means that the life of the church, theology and thus theological training, cannot do without Missiology (Niemandt 2014:39). If Christian theology and Christian churches understand the need to show respect to the surrounding context, if it is important to communicate God to the context, if the imperative to bring context into the kingdom is understood; then Missiology, with its particular emphasis on incarnation, contextualisation and enculturation, will come into play (Niemandt 2014:39).

If Missiology dreams of the continuation of its role in training and facilitating traders, it needs to focus on mission as contextualisation. Mission as praxis is about concrete transformation; it is, specifically, about transformative encounters: among people, and between the living God and his people (Kritzinger 2011:49-52).

\section{Contextualisation and incarnation}

The incarnation is thus a key paradigm for contextualising the church. The Bible is, by its very nature, contextual. Niemandt argues: 'It is an incarnational analogy in its union of the human and divine. In taking different shapes according to the context, the church is following a wellknown pattern in adapting itself to the setting' (Niemandt 2014:41). Jesus' mission is incarnational. Flemming (2013:84) says that the church must follow, following Jesus' lead, and that both the proclamation of the gospel and living the good news must be contextualised for particular people and occasions. Tennent argued that the incarnation is the ultimate example of what we call the translatability of the gospel' (2010:loc.3616-3617).

Jesus' mission was inclusive and boundary breaking. Flemming (2013) states:

The good news, by its very nature, crosses boundaries. It resists any single, standardized cultural expression. The Spirit leads the church on a journey into new ways of articulating the faith, as it encounters new circumstances. (p. 156)

To be incarnational, we have to cross boundaries, break down social constructionist symbolic fences and barriers, and build bridges that create the possibility of open communication and interaction. Kok and Niemandt (2009:6) argue that the church needs to be incarnational instead of attractional: Jesus's incarnational ethos results in the bringing of the presence of God into marginalised places or spaces, where such presence is usually believed not to be found. Crossing boundaries mean to focus on being church in the world, mostly in marginalised, liminal spaces. Bosch $(1991: 512,513)$ understood the incarnation in relation to the plight of the marginalised and recognised the fact that liberation theology viewed Christian mission in terms of the incarnate Christ. Bevans and Schroeder (2004:386) also link the incarnation to contextualisation as missiological imperative.

The close relation between contextualisation and incarnation is clear. Insights in the ideas on incarnation shape and enrich the concept of contextualisation.

\section{Incarnational and deep incarnation}

One of the big challenges facing Missiology is to break through the barriers of the discipline's strong anthropological focus, and to embrace the whole of created reality in its scope and reflection. Theology of Mission can assist this breaking through barriers by embracing the posture of 'traders' and creatively linking contextualisation, incarnation and deep incarnation.

'Deep incarnation' has been summarised as the cominginto-flesh of God's eternal Logos. In the process of incarnation, God the creator and the world of the flesh are conjoined in such depth that God links up with all vulnerable creatures. In Christ, God enters into the biological tissue of creation in order to share the fate of biological 
existence. In the incarnate One, God becomes Jesus, and in him God becomes human, sharing the life conditions of the least in creation. The most high and the very lowest are united in the process of incarnation. Gregersen (2015a:loc.367-370) argues that incarnation is the story of God's reach into the very tissue of material and biological existence. Deep incarnation clearly shows that God accepts and incorporates material existence in a divine embrace (Gregersen 2013:375). In summary, deep incarnation can be described as the presence of God in the past, present and future of the whole cosmos; the co-existence of the embodied Logos with the divinity of God. It underscores Jesus Christ, God incarnate, as the ecological centre of all creation, and facilitates all things interconnected to find their unity and wholeness in relationship to God (Niemandt 2017:252).

It is clear that the major themes of deep incarnation (such as e.g. an orientation towards life in the broadest sense, the importance of suffering and marginality, the nature of unity and community etc.) support Bevans' (2016:465) case for a missiological move from an anthropocentric understanding to one that focuses on the entire creation: 'Deep incarnation supports the mission move from an anthropocentric understanding of mission to one that has the entire creation at heart'.

\section{Deep contextualisation}

Perhaps, given the familiarity with mission as contextualisation, one needs to talk about mission as 'deep contextualisation'. Whereas 'incarnation' has a soteriological focus, contextualisation has a more missiological impetus. Mission as deep contextualisation will attempt to proclaim the gospel and actualise the good news for all occasions and in all histories, including 'deep history' (Gregersen 2013:370, 376) and the relationship with the origin of all creation.

Deep contextualisation might represent a way to include a post-anthropomorphic discourse in Missiology. It can assist with the reorientation of the history of mission on the whole of history and, thus, also deep history. Missiology also needs to recognise a sense of the extensiveness and evolutionary depth of the body of Jesus (Gregersen 2013:379).

Wright (2010:loc.234) made a strong case that God's mission includes the whole of creation. God's mission is the redemption and renewal of God's whole creation. Deep contextualisation, following the ideas argued in the discourse on 'deep incarnation', represents a reorientation of the whole of creation. Gregersen (2015b:loc.5640-5641) explains the argument for 'deep incarnation': 'Because salvation means being embraced by God's self-embodying Logos/Wisdom who is interweaved with the complex material-spiritual world of creation for the sake of its transformation'. Deep contextualisation recognises the ongoing dialogue between text and context, where the new context presupposes an appreciation for 'deep' history and the evolutionary nature of creation.
Deep contextualisation respects every context and sensitises missiologists to the power and persistent influence of colonial mission enterprises. Bosch (1978) warned against the colonial character of mission:

Mission is synonymous with Western domination, it is the remnant out of the colonial period. The missionary is 'the apostle of affluence, not sacrifice; cultural superiority, not Christian humility; technological efficiency, not human identification; white supremacy, not human liberation and community'. (pp. 237-238)

The relationship between mission and Missiology on the one hand, and colonialisation and coloniality on the other is still keeping theologians occupied in crucial theological discourses. The concept of deep contextualisation echoes the ideas of Grossfoguel (2011:3) when he pleads for a decolonial epistemic perspective that recognises a broader canon of thought than simply the Western canon. He argued that a universal decolonial perspective cannot be based on an abstract universal (one particular that raises itself as universal global design), but would have to be the result of the critical dialogue between diverse critical epistemic, ethical or political projects towards a pluriversal, as oppose to a universal, world. Grosfoguel's ideas support the plea for deep contextualisation when he argues that 'the decolonization of knowledge also would require to take seriously the epistemic perspective/cosmologies/insights of critical thinkers from the Global South thinking from and with subalternized racial/ethnic/sexual spaces and bodies' (Grossfoguel 2011:3).

Deep contextualisation also focuses on the future. Moltmann reminded us that the creator God is also the God of the future. He argues that the risen Christ is not just a hope for eternal life given to mortal human beings; he is also the future of all things in a 'new heavens and new earth' (Moltmann 2015:loc.1890). Deep contextualisation is about hope. It will recognise God's acceptance and embrace of the cosmic aspects of the world and the renewal and recreation of all created reality from the inside out (Gregersen 2013:383). God bestowed on humans freedom and creativity through the mechanism of evolution: 'God has entrusted creation to human beings not merely as caretakers of a past condition but as co-creators with God of the future' (Haight 2014:loc.1825). Created reality is an open system that includes a vast range of possibilities and unpredictable novelty. Deep contextualisation reminds us that this open system is a network in which human beings are an intrinsic part of the evolutionary network of life and the incomprehensible cosmos. We need to listen to, and discern, God's loving presence in the whole of creation and we need to seek 'Christ's crucifixion in that context which opens what is for the kingdom still to come' (Meylahn 2012:72).

In summary, deep contextualisation might assist Missiology to break through the barrier of limiting discourses on contextualisation to anthropological issues (see Figure 2). 


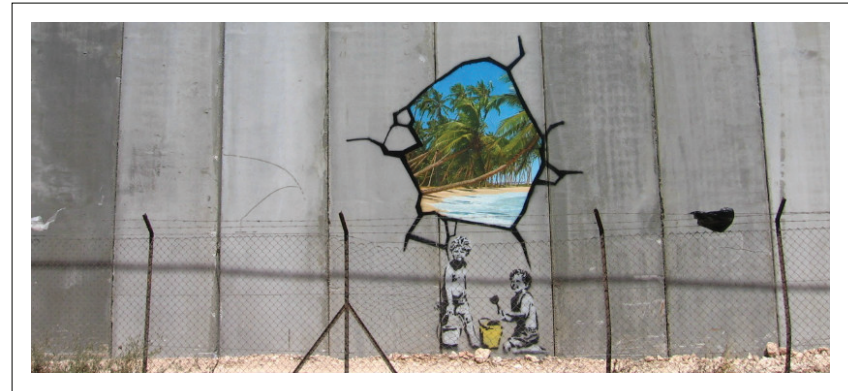

Source: Banksy, banksy-unwelcome-intervention-2005, 2005, viewed 11 June 2017, from http://www.artlyst.com/features/top-10-banksy-works-art/banksy-unwelcomeintervention-2005/

FIGURE 2: 'Unwelcome Intervention', Banksy mural on the West Bank Barrier, Qalqilya.

\section{Conclusion}

As contexts change, and as long as the ever-changing rhythms of different times beat over the world, Missiology, with its particular sensitivity towards contextualisation and its ability to facilitate the crossing of borders, will be needed to guide the church and theology in crossing barriers and imagining God's future (Niemandt 2014:39-40). Any dialogue on the future of Missiology as a theological discipline, and any discourse on walls, gateways and traders, and theology of the road, will acknowledge the important and indispensable role of Missiology in assisting the church and theology to artfully cross borders and navigate the storms of change. Meylahn (2012:72) also reminds us of the importance of traders, or, as he calls them, holy fools, with their openness towards the kingdom still to come, a breaking down of walls (deconstruction of the past), so as to open it for what is still to come. ${ }^{4}$

The 2017 centenary celebrations at the Faculty of Theology recall the history of the faculty and its partner churches and dreams of God's preferred future. The centenary festivities are accentuated by the honorary degree bestowed on Prof. Dr Jürgen Moltmann. Perhaps the argument can be concluded in the words of Moltmann (1967):

The Christian Church has not to serve mankind in order that this world may remain what it is, or may be preserved in the state in which it is, but in order that it may transform itself and become what it is promised to be. (p. 327)

\section{Acknowledgements Competing interests}

The author declares that he has no financial or personal relationships which may have inappropriately influenced him in writing this article.

\footnotetext{
4.May the Holy Fools inspire the church to struggle with remaining open towards God world and kingdom to come, open to the folly of the cross as she challenges and deconstructs the ways of the world by being church in but not for the world. May the holy fools inspire a messianic church foolishly standing in the cracks, in the presence of the broken body from where emerges a church in but not of the world (Meylahn 2012:73).
}

\section{References}

Banksy, 2005, Banksy-unwelcome-intervention-2005, viewed 11 June 2017, from http://www.artlyst.com/features/top-10-banksy-works-art/banksy-unwelcomeintervention-2005/

Banksy, 2017, Graffiti by Banksy, viewed 11 June 2017, from https://za.pinterest.com/ $\mathrm{pin} / 568368415444680021 /$

Bevans, S., 2016, 'Together towards life and the Evangelii Gaudium: Life and joy in dialogue', in K.R. Ross, J. Keum, K. Avtzi, \& R.R. Hewitt (eds.), Ecumenical missiology: Changing landscapes and new conceptions of mission, Regnum Edinburgh Centenary Series, vol. 35, pp. 461-472, Regnum, Oxford.

Bevans, S. \& Schroeder, R., 2004, Constants in context: A theology of mission for today, Orbis, Maryknoll, KY.

Bosch, D.J., 1978, Introduction to missiology ('Sendingwetenskap') at Unisa, Unpublished lectures.

Bosch, D.J., 1991, Transforming mission: Paradigm shifts in theology of mission, Orbis, Maryknoll, NY.

Bosch, D.J., 1995, Believing in the future: Towards a missiology of Western culture, Trinity Press, Valley Forge.

Fairclough, N., 2013, Language and power, 2nd edn., Routledge, Abingdon.

Flemming, D., 2013, Recovering the full mission of God: A biblical perspective on being, doing and telling, InterVarsity Press, Downers Grove, IL.

Friedman, T.L., 2016, Thank you for being late: An optimist's guide to thriving in the age of accelerations, Allen Lane, London.

Goheen, M.W., 2014, Introducing Christian mission today: Scripture, history and issues, InterVarsity Press [Kindle Edition], Downers Grove, IL.

Gregersen, N.H., 2013, 'Cur deus caro: Jesus and the cosmos story', Theology and Science 11(4), 370-393.

Gregersen, N.H. (ed.), 2015a, Incarnation: On the scope and depth of Christology, Fortress Press [Kindle edition], Minneapolis, MN.

Gregersen, N.H., 2015b, 'Deep incarnation: Opportunities and challenges', in N.H. Gregersen (ed.), Incarnation: On the scope and depth of Christology, loc.5548-5831, Fortress Press [Kindle edition], Minneapolis, MN.

Grossfoguel, R., 2011, 'Decolonizing post-colonial studies and paradigms of political economy: Transmodernity, decolonial thinking, and global coloniality', Transmodernity: Journal of Peripheral Cultural Production of the Luso-Hispanic World 1(1), 37.

Haight, R., 2014, Spirituality seeking theology, Modern Spiritual Masters Series, Orbis, Maryknoll, KY.

Kim, K., 2009, Joining in with the spirit: Connecting world church and local mission, Epworth, London.

Keifert, P., 2006, We are here now: A new missional era, Allelon, Eagle.

Kerkbode, 2015, NG Kerk se nee vir Gay-verhoudings, viewed 28 March 2017, from http://kerkbode.christians.co.za/2016/11/10/ng-kerk-se-nee-vir-gay-verhoudings/

Kok, J. \& Niemandt, C.J.P., 2009, '(Re)Discovering a missional-incarnational Ethos', HTS Teologiese Studies/Theological Studies 65(1), Art. \#274. https://doi.org/10.4102/ hts.v65i1.274

Kritzinger, J.N.J. \& Saayman, W., 2011, David J. Bosch: Prophetic integrity, cruciform praxis, Cluster, Dorpspruit.

Kritzinger, K., 2011, “'Mission as..." must we choose?', Missionalia 39(1-2), 32-59.

Meylahn, J.-A., 2012, Church emerging from the cracks: A church IN, but not OF the world, SUN Press, Stellenbosch.

Moltmann, J., 1967, Theology of hope, SCM, London.

Moltmann, J., 2015, 'Is God incarnate in all that is?', in N.H. Gregersen (ed.), Incarnation: On the scope and depth of Christology, loc.1836-2041, Fortress [Kindle edition], Minneapolis, MN.

Niemandt, C.J.P., 2014, 'Artisanal cheeses or artisanal Jesus - loving your postal code enough to reflect it in the life and theology of the church', Missionalia, 42(1/2), 38-54. https://doi.org/10.7832/42-1-2-45

Niemandt, C.J.P., 2017, 'Missiology and deep incarnation', Mission Studies 34, 246-261.

Pink Floyd, Another brick in the wall - Part 2, viewed 14 March 2017, from http:// www.pink-floyd-lyrics.com/html/another-brick-2-wall.html

Smit, Q., 2016, 'Dit gaan oor mag'. E-Kerkbode, 2 December 2016, viewed 10 March 2017, from http://kerkbode.christians.co.za/2016/12/02/dit-gaan-oor-mag/

Tennent, T., 2010, Invitation to world missions: A Trinitarian missiology for the twentyfirst century, Kregel [Kindle edition], Grand Rapids, MI.

Wikipedia, 2017, Banksy, viewed 14 March 2017, from https://en.wikipedia.org/wiki/ Banksy

Wright, CJ.H., 2010, The mission of God's people: A biblical theology of the church's mission, Zondervan [Kindle Edition], Grand Rapids, MI. 